\title{
The Aśokan Empire
}

\begin{abstract}
This chapter introduces the first case study that serves as empirical referent for a Buddhist approach to statecraft in ancient times by considering the early kingdom of Aśoka. This chapter and the one that follows offer "proofs of concept" for the possibility of applying Buddhist ideas in the practice of politics and statecraft. Aśoka governed according to the dharma, meaning principles and policies that reflect Buddha's teachings, although Aśoka expressed his principles and policies in edicts written in nonreligious, nonexclusive language. Aśoka's rule was characterized by the promotion of nonviolence; social welfare; environmental protection; religious tolerance; political pluralism; the fair and compassionate administration of justice; and sound and responsive public administration meaning transparency, accessibility, impartiality, and accountability. His foreign policy was founded on principles of nonviolence, nonaggression, conciliation, stability, and improved understanding among international actors through diplomacy and mutually beneficial commerce. Aśoka even practiced the exercise of "soft power" by establishing medical facilities in foreign lands, sharing beneficial plants, and installing infrastructure beyond his immediate borders as acts of goodwill toward neighboring countries. While these governing principles and policies may be commonplace today, Aśoka, it should be remembered, governed in Asia in the third century B.C.E.
\end{abstract}

Keywords Aśoka Aśokan empire · Edicts 


\section{Who Was Aśoka?}

Historians generally consider Aśoka (c. 304-232 BCE) to be the paradigmatic leader who governed according to Buddhist principles and the closest approximation to the mythic cakkavatti discussed in Chapter $3 .^{1}$ In the West, he is most famously memorialized by H.G. Wells, who wrote:

Aśoka worked sanely for the real needs of men. Amidst the tens of thousands

of names of monarchs that crowd the columns of history, their majesties and graciousnesses, and serenities and royal highnesses and the like, the name of

Aśoka shines, and shines almost alone, a star. From the Volga to Japan, his

name is still honored. ... More living men cherish his memory today than

ever have heard the names Constantine and Charlemagne (Wells 1921 at p. 371$)$.

$\mathrm{He}$ is similarly heralded in ancient Indian, Sri Lankan, and Chinese legends. Separating the historical Aśoka from the legend, however, can be difficult.

We know that Aśoka was the grandson of Chandragupta Maurya (reign: 321-298 BCE). Chandragupta founded the Mauryan dynasty and was the patron of the great Indian political theoretician, Kautilya, who authored an early treatise on power and politics, the Arthaśhāstra. After an interregnum following the death of his father, Bindusara (reign circa: 297-273 BCE), Aśoka successfully prevailed over his brothers in a competition for the throne, and Aśoka assumed authority circa 269 BCE. Aśoka brought the Mauryan dynasty to its apogee and ruled virtually the entire Indian subcontinent (today, most of India, and much of Pakistan, Bangladesh, and Afghanistan) as a hegemonic power for nearly 40 years. His reign was a unique period of peace, unity, and prosperity on the subcontinent (Fig. 4.1).

Although extolled in ancient legends of the East, ${ }^{2}$ Aśoka is best understood through his own words, his "Edicts," 33 in all, which were etched in rocks, stone pillars, and other materials and posted throughout his empire during his lifetime (Basham 1982). ${ }^{3}$ For nearly two millennia, the messages of the Edicts were lost to history because they were written primarily in Brabmi, a language that became extinct within a few centuries 
2. INDIA in 250 B. C.

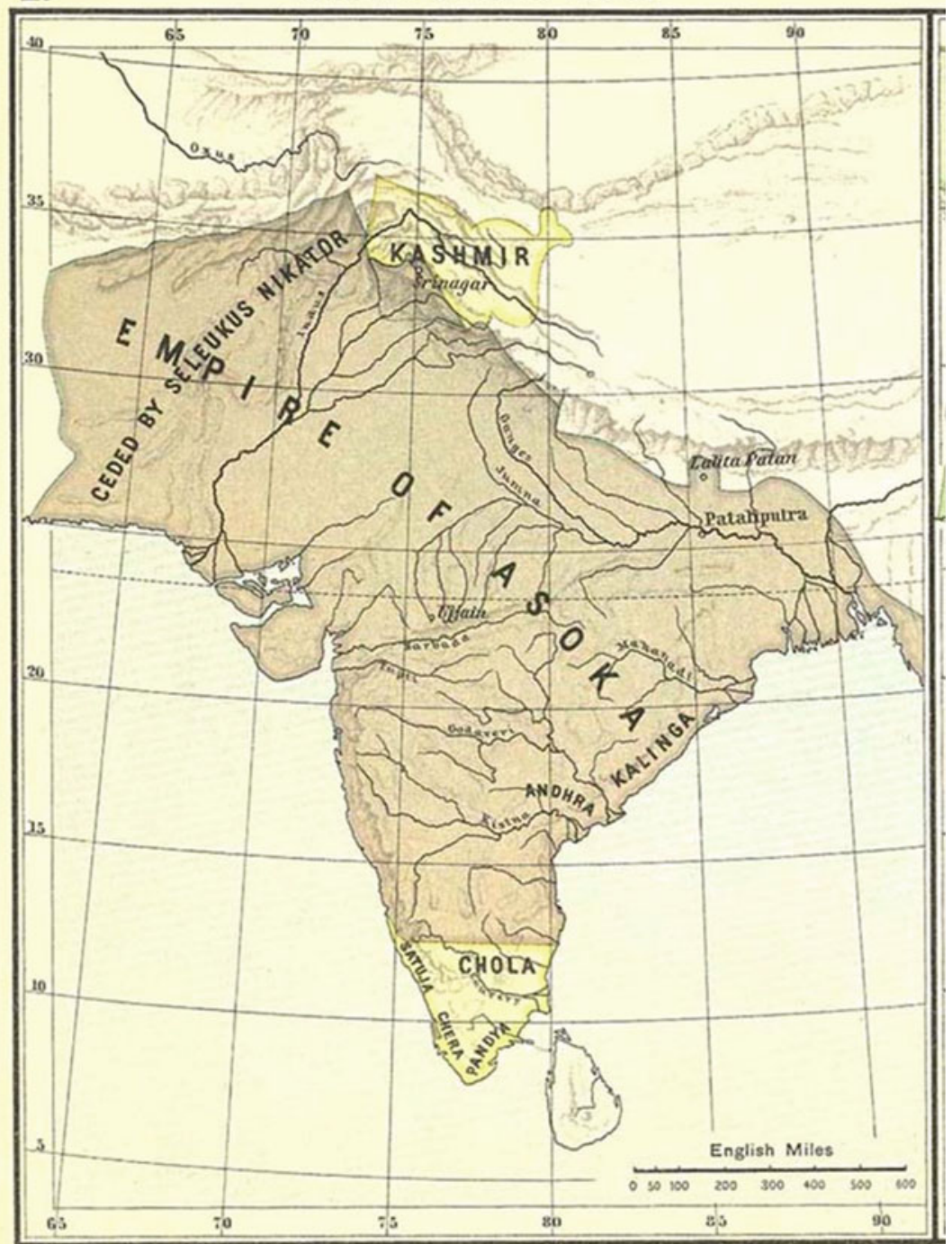

Justus Perthes, Gotha.

Fig. 4.1 India in 250 B.C. (From "Historical Atlas of India," by Charles Joppen [London: Longmans, Green \& Co., 1907], scan by FWP, Oct. 2006) 
of Aśoka's death. Eventually, the linguistic code was broken in the midnineteenth century, and since that time, the Edicts have been accepted as the standard for interpreting Aśokan politics (Tharpar 1997). Although one thinks of an edict as a sovereign's statement with the force of law, Aśoka's Edicts also included exhortations and persuasive writings and declarations of Aśoka's "devotion to the dharma," a phrase that has two intertwined meanings that will be explained below. Aśoka had three audiences for his edicts: most directly, his ministers; indirectly, all those people under his rule; and ultimately, posterity (Singh 2012).

\section{AśOKA's REIGN}

Following the consolidation of his empire through military conquest over the eastern kingdom of Kalinga (modern Orissa) eight years into his reign, Aśoka underwent a spiritual transformation, a metanoia or moral revolution. Reflecting that moral reckoning, Aśoka described in his own poignant words in Rock Edict XIII the great remorse he felt for the carnage, suffering, and displacement caused by his military campaign against the Kalingas ${ }^{4}$ :

When he had been consecrated eight years the Beloved of the Gods, the king Piyadasi [Aśoka], conquered Kalinga. A hundred and fifty thousand people

were deported, a hundred thousand killed and many times that number perished... On conquering Kalinga the Beloved of the Gods felt remorse...

the slaughter, death, and deportation of the people weighs heavily on the

mind of the Beloved of the Gods.

The experience marked an inflection point in his governance.

Aśoka henceforth dedicated his rule to the principles of charity and nonviolence, designed to serve his subjects and all living beings. $\mathrm{He}$ committed himself to rule according to the dharma in the First Pillar Edict, "For this is my principle: to protect through dharma, to administer affairs through dharma, to please the people with dharma, to guard the empire through dharma." 


\section{Two Notions of Dharma: Buddha Dharma and Aśokan Dharma}

In the Rock Edict I, thought to be the oldest edict, Aśoka discusses his conversion to Buddhism. ${ }^{5}$ Aśoka states in Minor Edict I at BairatCalcutta (Bhabra) that he became a lay devotee (upāsaka) dedicated to Buddha, the dharma (Buddha's teachings), and the sangha-the three "gems." One's commitment to the three gems constitutes the gateway to Buddhism. Aśoka describes how his practice of Buddhism strengthened three years after his conversion when he spent a year as a layman monk affiliated with the Buddhist sangha. His faith continued to strengthen over the course of his reign. Late in his life, he went so far as to issue a proclamation against those who might promote schisms with the Buddhist sangha ${ }^{6}$ and specify several Buddhist scriptures with which all Buddhist practitioners should be acquainted. Although Aśoka was a devout practitioner of Buddha's dharma personally; for example, he made highly visible pilgrimages to Buddhist holy places, erected shrines, and donated to Buddhist monasteries, he did not seek to make Buddhism the state religion, convert his subjects or others outside his kingdom to Buddhism, or discriminate against those who did not practice the Buddhist faith. In the Edicts, he rarely directly referred to Buddha's teachings, spoke in universal, humanistic terms, and promoted explicitly ecumenical policies toward all religions.

The contrast between Aśoka's strong personal beliefs and his nonsectarian policies, universalistic prose, and the general absence of theology or philosophy in the Edicts raises two critical questions. First, one may wonder, therefore, what Aśoka meant when he said his rule is dedicated to the propagation of "dharma." How was Aśoka using this term? Second, it prompts the question: "Was Aśoka a ruler who happened to be Buddhist, or was he a 'Buddhist ruler,' that is, one who governed according to Buddhist principles, even though he was genuinely nonsectarian and evenhanded in his rule and did not use his religion explicitly as a source of authority and legitimacy?" On this second question, scholars express a range of opinions. ${ }^{7}$ This author concludes that Aśoka was a Buddhist ruler, acting on Buddhist principles, although he usually presented them shorn of any explicit religious trappings.

Returning to the first question-what did Aśoka mean when he said he governs according to the dharma? Here, it is essential to begin the answer at the source, Aśoka himself. In the Second Pillar Edict, Aśoka poses the question, "What is dharma?" His answer: "To abstain from 
unwholesome deeds, to perform wholesome deeds, compassion, donation [generosity], truth, and purity [of mind]." In offering this definition note that, although Aśoka uses the same word, "dharma," that is often applied to Buddha's teachings, dharma has many meanings and in this context he was not referring to religious doctrine, per se. Aśoka's dharma was not preaching the way to Nirvana (he never uses that term in his Edicts) or teaching Buddha's Four Noble Truths, ${ }^{8}$ which is Buddha's dharma. Instead, he used the term to mean the worldly dharma of a cakkavatti; a humanistic civic doctrine based on common ethical principles contained in Buddhism (and in many other religions) that Aśoka believed would provide a practical and unifying standard of behavior for his heterogeneous empire, one conducive to prosperity, peace, and virtue. This interpretation is the more general meaning of the word "dharma," that is: "law, duty, justice, righteousness, virtue, the social or moral order; the unity of life" (Dhp. 2007 at p. 256).

Does Aśoka's use of dharma in this broader sense suggest that he was not a Buddhist ruler, but rather a worldly ruler who personally practiced Buddhism? I would answer, "no." Aśoka, by emphasizing the universal, nonsectarian, and practical value of his governing principles, was nonetheless acting consistent with Buddha's message and methods. Aśoka's emphasis on instructing on common truths that are practically useful parallels Buddha's approach to teaching his spiritual dharma. When Buddha was asked by an unlettered woman, "What is Dharma?" $\mathrm{He}$ replies, exactly like Aśoka's advice to his lay citizens: "To perform all wholesome deeds and to abstain from all unwholesome deeds and to continuously strive to purify one's mind is the dharma" (Dhp. 2007, p. 183). Buddha recognized that in teaching his dharma he should start with the universal and practical dimensions of his instructions. Buddha, like Aśoka, understood that what is most important to teach is not particular religious doctrine, specific rituals, or arcane philosophy, but fundamental ethical principles that will be helpful to all individuals right now and in the future. When asked why he did not teach all that he knows, such as answers to life's philosophical dilemmas, Buddha explained, "What do I not teach? Whatever is fascinating to discuss, divides people against each other, but has no bearing on putting an end to sorrow. What do I teach? Only what is necessary to take you to the other shore" (Dhp. 2007 at p. 58). Buddha, like Aśoka, was a pragmatic humanist; he did not speak of gods. Instead, he offered practical solutions to human problems in a way that would lead to lasting peace of mind. 
This down-to-earth orientation is especially evident in the early translation of Buddha's teachings in the Pâli Canon. Perhaps the most famous illustration of Buddha's preference for focusing on practical problems is found in the Cüla-Mālunkyaputta sütra, wherein Buddha eschews metaphysical speculations for their own sake through the parable of a man shot with a poisonous arrow who would die while demanding answers about the caste, clan, color, size, and hometown of his assailant before focusing on the need to have a physician remove the arrow (MN, 63, 1995)! So, too, Buddha said people should not waste time in metaphysical wonderings at the expense of failing to put his practical teachings on ending human suffering into practice. Aśoka, in promoting his worldly dharma, both within his empire and beyond, took his cue from Buddha and focused primarily on extolling ethical fundamentals designed to improve the personal growth and societal well-being of people, rather than the formal or metaphysical dimensions of his Buddhist religion. Aśoka, in his Edicts, chose to teach his citizens the aspects of the Buddhist path that are essential and immediately relevant to the creation and maintenance of a just and virtuous civic life (not the other shore of Nirvana), and he left out of his messages anything (including any aspects of his personal religious beliefs) that could divide his people or be interpreted as sectarian or exclusionary.

Consistent with his broad approach to dharma, in Pillar Edicts II and VII, Aśoka emphasizes the personal traits one should inculcate: goodness, little defilement, mercy, generosity, liberality, truthfulness, and gentleness. These qualities should be developed in fulfilling one's worldly duties to others including: respectful, reverential relationships with parents, elders, and teachers; liberality with friends, acquaintances, and relatives; appropriateness with slaves and servants; and protection for all living creatures. Those familiar with the Buddhist canon will recognize these instructions as directly parallel to those given by Buddha in the Sigālovāda sütra, but Aśoka makes no such reference to it in his Edicts. Likewise, in Rock Edict III, he encourages moderation in consumption and expenditure and care regarding one's speech. In Pillar Edict III he warns against malevolent attitudes such as impetuosity, cruelty, anger, pride, and malice. All these admonitions were consistent with Buddha's emphasis on the inculcation of basic virtues and positive emotions, the development of contentment, the practice of restraint, and the pursuit of the Middle Way, but Aśoka presents them as secular guidelines wholly apart from any specific, and thus exclusionary, religious mooring. Instead, 
Aśoka sought to personally embody and exemplify these qualities for his citizens, much like the virtuous ruler, the dharma-raja, in Buddhist parables, but Aśoka did not use religion as the basis of his authority or legitimacy. To put it simply, Aśoka knew that it was more efficacious to "act like a Buddha" than to "act like a Buddhist." So, in this author's interpretation, Aśoka was very much a Buddhist ruler, not just a ruler who was a Buddhist. I discuss below how many Aśokan policies comport with specific dimensions of Buddha's teachings.

While clearly animated by Buddhism, Aśokan dharma was nonsectarian and inclusive in its presentation. We might today call it a form of secular ethics. For Aśoka, dharma was the designation of ethical principles with a unifying and broad appeal to a wide swath of his citizens and a practical means of conforming behavior in the empire through the creation of a civic culture. Aśoka's dharma infused universal ideals-respect for the sanctity of all life, equality, charity, and compassion-into the everyday practice of citizens in a multicultural, multiethnic empire. He did not use religion cynically, but as a true believer, he identified and employed the universal principles of his religion to connect with all his subjects. This approach was consistent with Buddha's use of "skillful means" (upāyakauśalya): adapting one's teachings to the level of the audience's ability to understand the dharma, their spiritual potential.

For Aśoka, the essential instrument for inculcation of the dharma was not state policy or legislation but self-examination, introspection, or what we might today call mindfulness, contemplation, and meditation. Aśoka sought to elevate the ethical practice of citizens, not through an exercise of coercive political power or statute (although he used these too, for example outlawing ritualistic animal sacrifice), but through encouraging personal insight and meditation and by insuring that his government supported citizens in these efforts through good governance, sound and responsive administration, public works, social welfare, and transparency and equality under the law (Pillar Edict II). In Pillar Edict VII, he notes, "of these two [legislation and moral suasion], pious regulations are of small account, whereas persuasion is of greater value." This belief in the supportive role of government for citizen's personal development is also fully consistent with Buddha's political teachings: real change must come from within, and the government's and society's role should support individuals in these pursuits by providing conducive conditions for personal advancement and by demonstrating virtue in its policies and administration. For example, as will be discussed below, peace was a central tenet of 
Aśoka's rule. In Aśoka's dialect and in Sanskrit the word for peace, śānti, means "calming of one's own mind and the suppression of one's own mental and spiritual deficiencies and negative inclinations" rather than the Western reference to the absence of large-scale political violence (Salomon 2007 at p. 57). In Buddha's teachings, one cannot meaningfully change the world and create peace until one has mastered his or her own mind. Although there is no substitute for personal effort, there is a close connection between individuals' pursuit of the dharma and the goals of the state. They are mutually reinforcing: personal cultivation improves the larger society, and appropriate social, political, and economic policies of the state, in turn, support individuals in their personal development. Aśoka praised both personal and official efforts designed to create this integrated moral and political order. In their translation of the Edicts, Nikam and McKeon conclude that Aśoka's dharma "provides a code of personal conduct, a bond of human relations and political justice and a principle of international relations, and dharma turns the lives of men [sic] away from evil deeds, mutual intolerance, and armed conflict.... the whole political organization was made subsidiary to moral law in a concrete translation of the law into specific forms of human relations" (Nikam and McKeon 1959 at pp. 19-21).

Aśoka's dharma was truly revolutionary. Bruce Rich asserts: “Aśoka's revolution is one of public as well as private morality. A daring attempt to move Kautilyan society toward transcending its grounding in an ethic of power, force, and wealth to one evolving toward nonviolence, tolerance, and charity" (Rich 2010 at pp. 131-132). As Tharpar notes, "Religious texts of the time stressed man's responsibility to his religion and to his ancestors. To these Aśoka added yet another responsibility, perhaps the most important, that of responsibility to one's fellow human beings ..." (Tharpar 1997 at p. 271). Empires of the ancient world were founded and governed by ruthless monarchs, and their external relations were characterized by constant conflict, not peace. Viewed against this norm, we can begin to appreciate the uniqueness of Aśoka's doctrine of nonviolence, ethical development, and mutual care. As distinguished Indologist Richard Salomon maintains, "even a cursory study of the history of ancient India suffices to show that war was the rule and peace very much the exception," that exception was the kingdom of Aśoka (Salomon 2007 at p. 60).

Aśoka possessed a paternalistic conception of his monarchy, combining affection with authority, delight with duty. He explicitly states in Kalinga 
Rock Edict I that his citizens should come to realize "that the king is like a father, and that he feels for them as for himself, for they are like his own children to him." This attitude extended beyond his kingdom too, embracing all of mankind: "all men are my children; and, just as I desire for my children that they may attain every kind of welfare and happiness both in this world and the next, so do I desire for all men." In Pillar Edict IV, he further instructs his appointees to adopt the same protective attitude; as if they had been entrusted with the care of Aśoka's children. This benevolent authoritarianism of Aśoka differs somewhat from the Buddhist ideal of kingship, however. Buddha, in his teachings, idealized the monarch as a "great elect," one chosen by the people and ultimately responsible to them. ${ }^{9}$ By Aśokan times, however, republican states and more democratic monarchies had been subsumed by everlarger, more centralized and more controlling monarchies, and Aśoka's empire reflected this authoritarian trend. ${ }^{10}$ Aśoka's notion of kingship was benevolent but also more absolute than the Buddhist ideal.

\section{Aśokan Policies}

Beyond these general governing principles, the Edicts also describe the chief characteristics of Aśokan policy and administration. As noted, the first principle was nonviolence, which for its time, and perhaps for any time, made Aśokan governance exceptional. Policies of nonviolence are most evident in Aśoka's renunciation of the use of offensive war in statecraft. He recommended the same for his successors, although he allowed in Rock Edict XIII that, if his heirs must resort to warfare, it should be accompanied by "mercy and light punishments." Aśoka was not a pacifist, however. He did not disband his army, and the use of force defensively remained an available option if necessary for the security of his kingdom. Aśoka also limited state violence as a tool in the administration of justice for criminal offenses, although he did not eliminate capital punishment. Consistent with his Buddhist beliefs, nonviolence or reducing violence was a policy that Aśoka applied to all living beings, not just humans. In this respect, Aśoka was not an absolutist, but he refrained from eating living beings, outlawed ceremonial animal sacrifice, and reduced the use of meat in the royal kitchen (limited to two hens and one deer per day). He restricted hunting and fishing practices by protecting certain species and banning killing on certain dates and he gave up the traditional practice of royal hunts as a diversion, instead using his travel as an opportunity 
to explore sights of religious significance and to share the dharma with his subjects.

Second, Aśokan policy was characterized by strong social welfare initiatives and the provision of expanded public works. Several scholars have noted that Aśoka's policies contained the seeds of the modern welfare state (Sarkisyanz 1965; Tharpar 1997; Singh 2012; Rich 2010). Aśoka himself proclaims in the Sixth Pillar Edict "Thus do I provide for the welfare and happiness of the world - in the same way as I bring happiness to my relatives, both close and distant and work for it, so do I provide for all classes." Perhaps most significant in this regard was Aśoka's policies of providing medical care for his citizens and foreign travelers through the construction of public hospitals and clinics. He further provided for the care of animals via the creation of veterinary centers. Aśoka constructed roads, dams, and irrigation facilities. He planted medicinal trees and herbs inside and outside his kingdom for their beneficial public health effects. In Pillar Edict VII, he describes how he provided rest houses, wells, and shade trees along trade routes for the benefit of citizens and foreign travelers. According to Rock Edict II, Aśoka extended these charitable works beyond his own kingdom to Ceylon (Sri Lanka), the Near East (Syria), and Greek territories near his borders - an early form of foreign assistance.

Aśoka's policies also reflected an environmental awareness that is consistent with Buddha's guidance to live in harmony with the natural world given the interdependence of all living things. As noted, he attempted to ban or limit the unnecessary killing of animals, specifying in detail in Pillar Edict V protected classes of animals. He prohibited the burning of animal habitat as a technique for clearing agricultural lands or driving animals for a hunt, he outlawed the feeding of animals to other animals, and he sought to improve cultivation of agricultural and medicinal crops.

The Aśokan principles of tolerance, pluralism, and dialogue are best seen in his policies promoting the practice of all religions and encouraging mutual understanding among people of all faiths. Aśoka's Edicts promoted not only Buddhism but also traditional Brahmanical sects and those of the "śramanas" (those practicing outside the mainstream). ${ }^{11}$ In Rock Edict VII, Aśoka acknowledges that all sects encourage self-restraint and personal purification and, therefore, he desires that they should all dwell anywhere in his empire. He further recommends in Rock Edict XII that all people should appreciate and listen to the teachings of religions other than their own to recognize their underlying ethical unity. 
Aśoka's policies went far beyond mere passive "tolerance" of other religions to include an active engagement, "inter-faith dialogue" in modern terms, an effort to appreciate and learn from other traditions. In Rock Edict XII he cautions: "whosoever honors his own sect and condemns the sect of others wholly from devotion to his own sect...injures more gravely his own. Therefore, concord is to be commended, so that men may hear one another's principles and obey them." Aśoka recommended generosity toward the Brahmins and śramanas in the Ninth Major Rock Edict and, leading by personal example, Aśoka dedicated large sums for the housing of ascetics of the Ajivika and Jain sects, noted in the Barabar Cave Inscriptions, not just for the Buddhist sangha.

Aśokan policies advocated for rule of law and the impartial administration of justice consistent with Buddha's principle of the equality and dignity of all human beings. In Pillar Edict IV, he says "there should be uniformity in judicial proceedings and punishments," a remarkable phrase that has been read in two ways. More narrowly, this directive has been interpreted to mean that Aśoka was mandating uniformity in the application of the law throughout all geographic areas of his empire. If so, this was an important call for consistency and fairness in rule of law. Aśoka's call for uniformity in judicial proceedings and punishments has also been interpreted more expansively to suggest that Aśoka was mandating that law and the administration of justice should not discriminate by caste, class, or occupation unlike the prevailing Brahmanic tradition that distinguished offenders and punishments by caste and position. If so, then Aśoka's words were mandating full equal justice before the law for all citizens (Rich 2010). Although either reading would constitute an important step in the advancement of social justice, in the broader meaning, the Edict's pronouncement would have been a breakthrough in terms of human rights and equality consistent with Buddha's rejection of social caste and hierarchy.

Aśokan policies also tempered justice with mercy. He encouraged his rural administrators to be both fair and moderate in their administration of justice. Aśoka did not do away with the death penalty, but, he instructs in the Fourth Pillar Edict that judges must provide a three-day respite to any prisoner sentenced to death so that their family may appeal the order and, even if unsuccessful, the prisoner may have time to undertake final good works in preparation for his next life. In his Fifth Major Rock Edict, Aśoka promotes the welfare of prisoners more generally: advocating for the release of those who have children, are afflicted, or aged. In his 
Fifth Pillar Edict, he remarks that he has released one prisoner for each of the 25 years of his reign. To ensure that officials were not abusing their judicial authority, Aśoka instituted triennial and quinquennial surveillance tours from the central government, what we might call policy audits, and he personally participated in these efforts.

In addition to the fair and compassionate administration of justice, Aśoka was also an early advocate of policies of "good governance," meaning transparency, accessibility, impartiality, and accountability. He warned his administrators to avoid weaknesses such as anger, laziness, impatience, and any kind of prejudice and, as noted, he followed up on his admonitions by sending a royal or provincial inspector to insure his directives were followed. Through his Edicts, his travels, and the peripatetic nature of his administrators, Aśoka underscored that regular communication with his subjects was a major policy priority. Aśoka was committed to a policy of personal accessibility and sought to demonstrate his commitment to good governance. For example, he commits to be available to his citizens stating in Rock Edict VI: "In all places do I dispose of the affairs of the people ... [important information] should ... be reported to me in all places, at all hours." He adds, "I never feel satisfaction in my exertions and dispatch of business. For work I must for the welfare of all the folk ... the root is energy ... for nothing is more essential than the welfare of all the folk." In the Edicts, he exhorts his administrators to efficacy and hard work. "Transparency, efficiency, and exertion" was the motto of his governance.

S.J. Tambiah summarizes Aśoka's policies as "protection and liberality" (Tambiah 1976 at p. 39). Bruce Rich describes the underpinnings of Asokan rule as "justice, prudence, and beneficence" (Rich 2010 at p. 129). The resemblances between Aśoka's ideals and policies with the principles of the European Enlightenment in terms of equality, rationality, tolerance of dissent, freedom of belief, and justice under the law, and the parallels between Aśoka's social policies and those of the modern welfare state, are obvious, but recall that Aśoka was writing in Asia in the third century BCE. For historical comparison, this was the Warring States period in China. 


\section{Aśoka's Foreign Policy}

Aśoka's message of acceptance of diversity, good works, tolerance, and nonviolence also extended to his foreign policy and his treatment of foreigners within the empire. The promotion of the dharma was also the hallmark of Aśokan foreign policy. For example, in Rock Edict I he states: "The Beloved of the Gods [Aśoka] considers victory by dharma to be the foremost victory ... [and] has gained this victory on all frontiers to a distance of 600 yojonas (about 4000 miles)" (Tharpar 1997).

Recall, following his remorse over the bloodshed and suffering of the Kalinga war, Aśoka foreswore future military aggression as an instrument of policy (a promise he kept) and vowed to engage only in peaceful "conquest by dharma." 12 This reference to conquest does not mean seeking political dominion over others or a religious crusade, but rather refers to the Buddhist notion of conquering of the self and coming to understand one's responsibilities for others as discussed in Chapter 2. For Aśoka, the essence of law, politics, and administration was insight into oneself and respect for others. Consistent with his word, he made propagation of dharma his main objective, and he pursued a statecraft of conciliation, stability, and security designed to reduce international tensions (Rock Edicts I, XVI).

Aśoka lived in a time of expanded communication and travel between the Eastern Mediterranean and South Asia. As part of his diplomacy, Aśoka dispatched emissaries (dharma ambassadors) to Ceylon, Egypt, Syria, Greece, Macedonia, Afghanistan, Kashmir, and the Himalayas and to the Cholas and the Pandyas, his immediate neighbors to the South (Zhang 2012). The stated goal of these foreign missions was not religious promulgation or conquest (although conquest was within Aśoka's powers in some cases) but promotion of mutual understanding, acquaintance with Aśoka's dharma, and economic betterment through commercial exchange. Aśoka established particularly friendly relations with Ceylon, his neighbor to the South and encouraged the spread of dharma there. Aśoka's foreign policies, like his domestic policies, were designed to be both morally correct and expedient and likely to prove beneficial to Aśoka's empire (Jayatilleke 1967). History does not reveal what reception his ambassadors received but Aśoka undoubtedly increased the stature and spread of his ideas throughout Asia (Bandarkar 1925; Gelblum 1957). Aśoka was an early practitioner of foreign aid and cultural diplomacy as instruments of statecraft. He practiced the exercise of "soft power" by 
establishing medical facilities in foreign lands, sharing beneficial plants, and installing infrastructure beyond his immediate borders as acts of goodwill toward neighboring countries.

Aśoka did not live in peaceful times and he had to govern a geographically vast and ethnically variegated empire, ${ }^{13}$ so his transition from violent conquest to forgoing aggression must have been challenging. Aśoka had to deal with tensions among social classes and religious sects, lawless people on his frontiers, and other nations and empires with vastly different political systems. Aśoka chose to address these challenges affirmatively. First, he developed and promulgated a unifying ethic, a civil dharma of social responsibility designed to raise people's moral outlook both within and beyond his borders. Second, in his actions, Aśoka pursued policies that advanced social welfare and happiness through good deeds, public works, and the provision of good governance or foreign assistance. In Rock Edict VI, he states "I consider the promotion of the people's welfare my highest duty.... I owe to all living creatures to make them happy in this world and help them attain heaven in the next" (Nikam and McKeon 1959 at p. 38). In this respect too, Aśoka was following Buddha's political teachings on what constitutes a just and legitimate monarch contained in the siutras of the Pali canon. ${ }^{14}$

\section{Aśoka's Forcefulness}

Lest one conclude that Aśoka was naïve in his approach to domestic politics or foreign relations in his appeal to people's better nature, it should also be noted that Aśoka's Edicts reveal a practical shrewdness, an understanding of power, and great skill in administrative control. Some interpreters of Aśoka's policies characterize Asoka's forcefulness as what one author calls "Buddhist realism," that is, Aśoka kept the requisites of putative power: a full treasury; a large, strong, and well-equipped army; and an extensive administrative structure (Tambiah 1976; Gokhale 1966). A more recent work describes Aśoka's empire "as a fusion of real politik and moral politik" (Shahi 2019 at p. 57; see earlier Albinski 1958). Recall Aśoka had inherited a philosophy of real politik from his grandfather and his grandfather's advisor, Kautilya, and a substantial bureaucracy from his ancestors.

While this is one possible interpretation of Aśoka's actions, viewed through a Buddhist lens, Aśoka's understanding and use of power could 
be interpreted as a form of "wrathful compassion"-strong actions motivated by love and compassion for those acted upon, although they appear to an outside observer as motivated by anger or desire for power. The best example of wrathful compassion in the West is the parable of Christ throwing the moneychangers out of the temple. Buddhism, especially in its later Mahayana and Vajrayana forms accentuates the wrathful compassion of Buddha's representations.

Aśoka's subtle exercise of tolerance with strength and compassion can be seen in his message to the lawless people on his frontiers:

Unconquered peoples along the border of my dominions may wonder what my disposition is toward them. My only wish with respect to them is they

should not fear me, but trust me; that they should expect only happiness from me, not misery; that they should understand further that I will forgive

them for offenses that can be forgiven; that they should be induced by my

example to practice dharma; and that they should attain happiness in this

world and the next (Nikam and McKeon 1959 at p. 53).

Implied in Aśoka's message, of course, is that he has the power to forgive, or not. In addressing the unruly forest dwellers of his empire, he was even more direct, warning them in Rock Edict XIII that they should follow his instructions so that, despite his avowed restraint, they may not be shamed or killed. Perhaps for these reasons, in her classic study, Tharpar concludes that Aśoka was a "stern monarch" (Tharpar 1997).

\section{CONCLUSION}

History does not provide a detailed record of Aśoka's empire. In the Indian library, philosophy and myth predominate and history is described as "the empty shelf" (Salomon 2007). ${ }^{15}$ We do know that he ruled a great and vast state of growing wealth and expanded commerce (based on archeological records) for nearly 40 years and the final 32 years were a unique time of both prosperity and peace on the subcontinent. Roughly 
50 years after Aśoka's death, the Mauryan empire fragmented for reasons that history can only speculate upon. ${ }^{16}$

\section{Notes}

1. Aśoka, in his writings, never refers to himself as a cakkavatti, instead describing himself as the "Beloved of the Gods," or by the name, "Piyadasi," meaning "one who sees affectionately" or "one who is of gracious mien" (Bandarkar 1925). Interestingly, the name Aśoka translates as "one without sorrow" or "one beyond sorrow," which is an appellation often applied to Buddha, himself, as he had transcended the sufferings of samsara.

2. A.L Basham explains that the legends of Aśoka described in Sri Lankan, Indian, and Chinese sources have little in common except that they describe a "mighty Indian ruler, whose capital was Pataliputra, and who adopted a new enlightened policy as a result of his conversion to Buddhism. Almost everything else is missing in one source or another" (Basham 1982 at p. 132).

3. The Edicts consist of fourteen Rock Edicts, seven Pillar Edicts, and miscellaneous site-specific Edicts, often found in caves.

4. Interestingly, for reasons of shame, sensitivity, or pragmatism, Aśoka did not post this message in Kalinga itself (Singh 2012).

5. Prior to his conversion, scholars believe that Aśoka practiced the prevailing Brahmanical religion and was said to be a devotee of Shiva (Gelblum 1957). It should be remembered that at that time Buddhism was an influential sect but not a major religion.

6. In the Rummindei Pillar inscription he declares: "No one is to cause dissension in the Order. The Order of monks and nuns has been united, and this unity should last for as long as my sons and great grandsons, and the moon and the sun. Whoever creates a schism in the Order, whether monk or nun, is to be dressed in white garments, and to be put in a place not inhabited by monks or nuns."

7. Some authors, such as Tharpar, assume a skeptical attitude toward the notion of Aśoka's rule as Buddhist (Tharpar 1997). Others, such as Bandarkar, Gokhale, and Kumar are inclined to see Aśoka's reign as a more direct extension of his Buddhist beliefs in the worldly sphere of politics (Bandarkar 1925; Gokhale 1948; Kumar 2017).

8. Following his enlightenment, Buddha's first teaching was on the Four Noble Truths: one must know life's sufferings; the causes of these sufferings; what is the end of suffering; and the path to liberation from suffering.

9. See, in particular, the Aggañña sūtra. 
10. While under siege from powerful monarchies and in retreat at the time of Buddha, republican forms of government in India likely began in the late Vedic period (the early first millennium BCE) and persisted in some form until the third or fourth century AD (Muhlberger 1998; Sarkisyanz 1965). "Republican" in the context of ancient India means that a larger group of individuals were involved in decision making and governance processes relative to monarchic states and that political practice reflected a preference for decision making by deliberation rather than command. The republics were not fully democratic, but they did involve collective decision making by select groups, families, castes, or occupations. This governance by discussion and limited enfranchisement can be viewed as a form of republicanism. Furthermore, K.P. Jayaswal notes that Buddha's sütras refer to ballot voting, majoritarian decision making, and referendums without definition, leading him to conclude that these political procedures must have been taken for granted by the time of Buddha's teachings (Jayaswal 2005).

11. In contrast to the dominant Brahmanical sects, the śramanas is a term that referred to those groups, including Buddhists but also the Ajivaka, Lokayata, Jaina, and the agnostic (Ajñana) sects, that went forth out of mainstream society and governmental control to wander and think freely without societal constraints, supported by alms and donations from followers and those attending their public lectures. Later, some of these groups, most particularly Buddhists, settled in enclaves near cities and along trade routes and developed codified principles in the governing laws for their communities. The śramanas generally believed that experience alone was the highest authority and that the universe is subject to natural, discoverable laws and that by understanding and living in accordance with these laws, human beings could find meaning. They rejected the prevailing religious justification for social hierarchy, advocated for the equality of all individuals in their potential for spiritual advancement, and promoted tolerance of personal difference. Buddha specifically rejected the Brahmanical myths of divine creation of the world and separation of humans by race and class.

12. Elsewhere, Aśoka specifically instructs his successors, sons, and grandsons to aim for victory by dharma, not military means.

13. Rock Edict II mentions ethnic groups such as the Yonas (those of Greek or Western ethnicity), Gandharas, Yavanas, Kambojas, Ristikas, and Pitinikas, within or at the outskirts of his empire.

14. See the Aggañña, Mahāsudassana, Cakkavatti-Sìhanāda, and Kūtadanta sütras.

15. Salomon notes: "In broad terms, Indian civilization is more concerned with the presentation and consideration of normative theories than in the recording of pragmatic realities" (Salomon 2007 at p. 53). 
16. See Romila Tharpar, Aśoka and the Decline of the Mauryas, 3rd ed., New Delhi: Oxford University Press, 1997. In Chapter 7 of this work, Tharpar dismisses several theories that attempt to explain the decline of the Mauryan empire by reference to military inactivity during Aśoka's reign, Brahmin resentment of his dharma, popular uprisings by restive groups, or economic pressures. Instead, Tharpar cites the general lack of a national consciousness on the subcontinent and the absence of strong leadership after Aśoka as reasons for the empire's decline.

\section{REFERENCES}

Albinski, Henry. 1958. The Place of Emperor Aśoka in Ancient Indian Political Thought. Midwestern Journal of Political Science 2 (1): 62-75.

Basham, A.L. 1982. Asoka and Buddhism-A Reexamination. The Journal of the International Association of Buddhist Studies 5 (1): 131-143.

Bandarkar, D.R. 1925. Asoka. Calcutta: Calcutta University Press.

Dhp. 2007. The Dhammapada, trans. Eknath Easwaran. Tomales, CA: Nilgiri Press.

Gelblum, Tuvia. 1957. The Spirit of Aśoka. East and West 8 (3): 261-271.

Gokhale, B.G. 1948. Buddhism and Asoka. Baroda: Padmaja Publications.

- 1966. Early Buddhist Kingship. The Journal of Asian Studies 26 (1): $15-22$.

Jayaswal, K.P. 2005. Hindu Polity: A Constitutional History of India in Hindu Times. Delhi, India: Chaukhamba Sanskrit Pratishthan.

Jayatilleke, Kulatissa. 1967. Buddhism and International Law. The Principles of International Law in Buddhism 120: 534-563.

Kumar, Harish. 2017. The Buddha Behind the Ashoka. Research Reinforcement 5 (2): 158-161.

MN. 1995. Majjhima Nikaya, The Middle Length Discourses of the Buddha, trans. Bhikkhu Nánamoli and Bhikkhu Bodhi. Boston: Wisdom Publications.

Muhlberger, Steve. 1998. Democracy in Ancient India. Unpublished Paper. Available at: http://faculty.nipissingu.ca/muhlberger/HISTDEM/ INDIADEM.HTM.

Nikam, N.A., and R. McKeon. 1959. The Edicts of Asoka. Chicago: University of Chicago Press.

Rich, Bruce. 2010. To Uphold the World: A Call for a New Global Ethic from Ancient India. Boston: Beacon Press.

Salomon, Richard. 2007. Ancient India: Peace Within and War Without. In War and Peace in the Ancient World, ed. Kurt Raaflaub, 53-65. Malden, MA: Blackwell Publishers. 
Sarkisyanz, E. 1965. The Buddhist Welfare State of Ashoka. In Buddhist Backgrounds of the Burmese Revolution, ed. E. Sarkisyanz, 26-32. Dordrecht: Springer.

Shahi, Deepshikha. 2019. Kautilya and Non-Western IR Theory. New York: Palgrave MacMillan.

Singh, Upinger. 2012. Governing the State and Self: Political Philosophy and Practice in the Edicts of Aśoka. South Asian Studies 28 (2): 131-145.

Tambiah, S.J. 1976. World Conqueror and World Renouncer. Cambridge: Cambridge University Press.

Tharpar, R. 1997. Asoka and the Decline of the Mauryas, 3rd ed. New Delhi: Oxford University Press.

Wells, H.G. 1921. The Outline of History: Being a Plain History of Life and Mankind. New York: MacMillan Company.

Zhang, Juyan. 2012. Buddhist Diplomacy: History and Status Quo. Los Angles: Figueroa Press.

Open Access This chapter is licensed under the terms of the Creative Commons Attribution 4.0 International License (http://creativecommons.org/licenses/ by $/ 4.0 /)$, which permits use, sharing, adaptation, distribution and reproduction in any medium or format, as long as you give appropriate credit to the original author(s) and the source, provide a link to the Creative Commons license and indicate if changes were made.

The images or other third party material in this chapter are included in the chapter's Creative Commons license, unless indicated otherwise in a credit line to the material. If material is not included in the chapter's Creative Commons license and your intended use is not permitted by statutory regulation or exceeds the permitted use, you will need to obtain permission directly from the copyright holder.

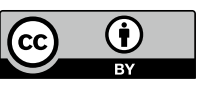

